\title{
Ex-UN AIDS chief is blasted for remarks on vaccine strategy
}

[WASHINGTON] The former director of the World Health Organization's Global Programme on AIDS, Jonathan Mann, has accused the US National Institutes of Health (NIH) of violating human rights by failing to proceed to large-scale clinical trials of AIDS vaccines.

His remarks were made in an address to the President's Advisory Council on AIDS (PACHA) last month shortly before the council proposed that leadership of AIDS vaccine development be moved out of NIH and into the White House Office of National AIDS Policy.

But leaders of NIH's effort to develop a vaccine argue that the remarks by Mann, who is now dean of the School of Public Health at Allegheny University of the Health Sciences in Philadelphia, are scientifically uninformed and inject politics unnecessarily into what should be a rational scientific debate.

"It's time that Dr Mann sits down with the data and looks at it," says David Baltimore, president of the California Institute of Technology, and head of a committee that advises NIH on AIDS vaccine research. "He should be involved in a scientific debate, not a political and rhetorical one."

Such sentiments are shared by Anthony
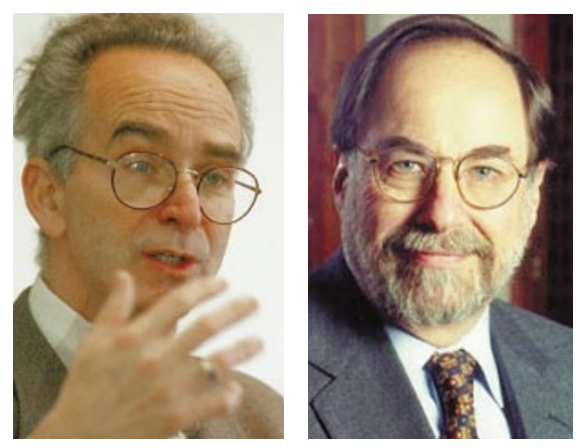

Mann (left) has irked Baltimore (right) and others with his criticism of NIH.

Fauci, the director of the National Institute of Allergy and Infectious Diseases: "It's unfortunate that Jonathan has put the difficulties that one encounters in vaccine development, and decisions about vaccine trials into the arena of human rights."

Addressing PACHA last month, Mann accused Baltimore and Harold Varmus, the $\mathrm{NIH}$ director, of incompetence and ethical failure because NIH has not launched largescale phase III clinical efficacy trials of any HIV vaccine candidate.

After their safety and immunogenicity have been demonstrated, "vaccine candi-

\section{South African drugs agency to be replaced}

[CAPE TOWN] South Africa's Health Minister, Nkosazana Zuma, announced last week that the Medicines Control Council (MCC), which has clashed with the government by consistently blocking trials of a controversial AIDS drug, will be replaced by a new Medicines Regulatory Authority.

The move follows clashes between government and the MCC about the drug Virodene. In January last year, three researchers at the University of Pretoria claimed to have found a cure for AIDS and appealed directly to cabinet for funds for further research. But the following month the MCC issued a report outlining the dangers of the drug, and halted the illegal clinical trials that were already taking place (see Nature 385, $474 \&$ 386, 6; 1997).

In January this year, the council again refused an application for clinical trials of Virodene, on the grounds that the drug contains a highly toxic industrial solvent, dimethylformamide, and that measurements to assess its effects had not been adequately developed.

Early last month the general secretary of the African National Congress (ANC), Kgalema Motlanthe, accused the MCC of "censoring" research on the drug. A week later, the deputy president Thabo Mbeki took the extraordinary measure of launching a stinging attack on the council. In an article written for two of the country's Sunday newspapers, Mbeki concluded that "the cruel games of those who do not care (about AIDS) should not be allowed to set the national agenda".

Mbeki also vehemently denied claims by the opposition Democratic Party that the ANC had been offered a six per cent financial stake in the company that has patented the drug, Cyropreservation Technologies.

The heads of the departments of medicine at five of the country's seven medical schools have expressed great concern at "political interference" in the functioning of the MCC. In a signed letter, the academics expressed support for the council, which they felt had "served the public of South Africa with the highest degree of integrity".

Zuma's decision to create a new authority follows the recommendation last month of a report on the council by an independent evaluation team. dates are ready to be tested in human trials", he said. Therefore "the federal government's failure to proceed to vaccine field trials is a human rights violation".

Mann claimed that Baltimore, a virologist and molecular immunologist who won the Nobel prize in 1975 for his co-discovery of reverse transcriptase, is "not equipped to develop an AIDS vaccine" and that, with Varmus, he is "holding a monopoly lock on the process".

"This is too big a problem to leave scientists in charge of," Mann said, arguing that the ten-member committee that Baltimore heads - and which is dominated by basic scientists - should feature equal representation byvaccinologists and public health experts.

Mann, a medical doctor with a master's degree in public health, charged that, because AIDS disproportionately affects the poor and minorities, vaccine development is progressing more slowly than it would if the affluent were primarily afflicted. He also argued that it is "unrealistic and illusory" to wait for scientific consensus on when a vaccine candidate is ready, pointing out that scientists had been in conflict before they launched field trials of vaccines such as polio.

Mann is not alone in his assessment of NIH's vaccine work. "The current federal AIDS vaccine effort is stalled in paralysing scientific debate and bureaucratic delay," PACHA said in a statement three days after his address. "It is only within the Office of the President that sufficient authority exists to ensure leadership, thorough coordination and collaboration of all requisite constituencies."

But Mann's speech has piqued NIH leaders, who say he is ignoring the scientific fact that no vaccine candidate is ready for clinical efficacy trials. They point, for example, to a recent study, reported in the Journal of Viro$\log y$, of 16 individuals who had become infected in phase I and phase II trials, despite vaccination with a gp120 vaccine, which relies for immunogenicity on a single subunit protein of HIV.

This paper concluded that the vaccine conferred no beneficial or adverse effects on the individuals. "There's an enormous amount of evidence here that the kinds of antibodies induced in vaccinees are not antibodies that can neutralize a virus, that can protect people," says Baltimore.

Baltimore says that Mann's arguments rely on generalities and historical analogies that do not pertain in the AIDS context, and when individual AIDS vaccine candidates are scrutinized. 
However, Mann is unapologetic. The consternation he has stirred up at NIH is "appropriate", he says. "I continue to fail to see the kind of clear, milestone-driven process [at $\mathrm{NIH}$ ] that includes not only the opinions of basic scientists, but the knowledge and experience of people who have developed vaccines."

His critics include Gregg Gonsalves, a spokesman for Treatment Action Group, a national AIDS research advocacy organization, who calls Mann's speech “outrageous and irresponsible". "There is this notion that there are these big bad NIH scientists standing in the way of phase III development of an effective HIV vaccine," says Gonsalves. "The real story is that we don't have an acceptable candidate to put into phase III trials right now."

Varmus declines to comment on Mann's statements. But Fauci, whose institute carries out most of NIH's AIDS work, called the statements "untrue" and said it was "inappropriate" for Mann "to personally attack Harold Varmus and David Baltimore".

In 1994, Fauci decided that NIH should not back phase III trials of two gp 120 vaccines (see Nature 369, 593; 1994). No other candidate has since been moved into such trials by NIH. But in January, VaxGen, a biotechnology company in South San Francisco, announced that it had gained the approval of the Food and Drug Administration to launch this year a privately funded phase III trial of gp120 vaccine in the United States and Thailand (see Nature 391, 220;1998).

As chair of the NIH's 15-month-old AIDS Vaccine Research Committee, Baltimore has been meeting scientists, studying candidate vaccines, and developing and awarding innovation' grants to encourage scientists to work in areas that are not being adequately explored. "There's a very extensive programme designed to understand and produce a vaccine," he says.

Baltimore says that progress on the vaccine is not being limited by NIH's unwillingness to test new candidates, "but by the limited number of opportunities being presented by the scientific community". He adds: "It's not necessarily anybody's fault. It's a very difficult problem."

Gonsalves rejects the advisory council's proposal that control of AIDS vaccine development be moved to the White House: "It's a scientific problem. Our best resources, our best talent are at the NIH. And that's where the job should be done." Meredith Wadman

\section{New Chinese premier takes on the reins of scientific reform}

[токуо] China's new and outspoken premier, Zhu Rongji, seems likely to champion science and technology. He has already taken personal charge of making increased support for science a reality, a measure promised by his government.

In his first press conference after his appointment at the end of last month, Zhu lambasted the waste of government money in what he called an "excessive" number of government bodies and projects, and complained that this has been depriving science and technology of necessary funds.

$\mathrm{Zhu}$, a tough and talented reformer, is believed to be the principal architect of recent reforms that have reduced the number of state ministries and commissions from 40 to 29, and have also resulted in the State Science and Technology Commission being converted into a ministry (see Nature 392,220 ; 1998).

Furthermore, he will chair a powerful, newly reconstituted committee for science, technology and education - its forerunner was restricted to science and technology alone - in the State Council, the highest body for the day-to-day running of the country, which is headed by Zhu himself.

A senior member of the Chinese Academy of Sciences says he "applauds" the determination and drive of the new premier, and predicts that Zhu's committee will play a "crucial" role in implementing policy and revitalizing China through science and technology.

He is also optimistic that Zhu will push forward a promised government programme to pump 2.5 billion yuan (US\$300 million) into basic research over the next five years, although he points out that the definition of "basic research" remains "somewhat controversial" in China.

The new government has already said that it plans to increase spending on science

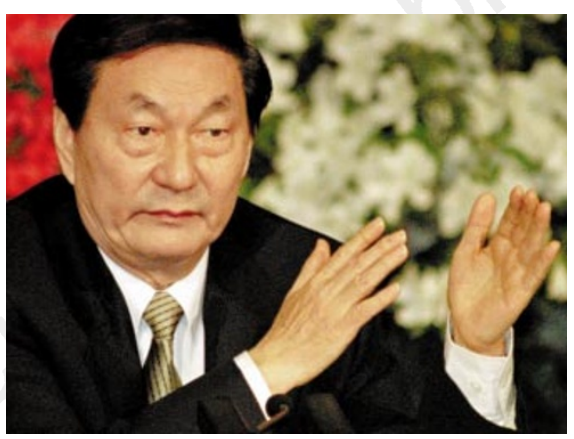

Zhu Rongji: the premier's committee will be crucial for implementing science policy.

this year by 12.6 per cent, to a total of 12.5 billion yuan. But the head of the newly formed Ministry of Science and Technology, Zhu Lilan, a polymer chemist, seems likely to emphasize development more than basic research.

In an interview with the People's Daily newspaper on 30 March, she pointed out that in developed countries expenditure on basic research compared with development and commercialization falls into the ratio of $1: 10: 100$. But in China the ratio is about 1:0.5:100.

"We need to look closely at the conditions and environment that slow down the transfer of scientific and technical results to industry," the newspaper quotes Zhu Lilan as saying. She added: "As a developing country, we need to concentrate our resources in order to make strategic breakthroughs. We can't afford to scatter our investments thoughtlessly."

But the new science minister also calls for more creativity and innovation. "We need to create an environment in which young people can step forward from the crowd and sing their own song."

It remains unclear what effect the conversion of the State Science and
Technology Commission to a ministry will have. On paper, stepping down from the State Council reduces its status. But it is expected to continue to play a leading role in setting science and technology policy, and as a ministry it will be able to fund its own research, rather than channelling funding through other ministries.

However, Western observers in Beijing point out that changes in central government alone will be insufficient to bring about drastic reform, as in China considerable power and budgets are wielded by provincial governments. Changes mirroring the reform of central government are not expected in the provinces until next year, and it remains to be seen whether they will fully implement the reforms desired by leaders in the central government.

Furthermore, one of the biggest problems facing China's research system is the lack of coordination between different branches of the government, both central and provincial. One factor holding back the development of the Internet for scientific use in China, for example, is the lack of good connections between the network of the Chinese Academy of Sciences and the computer network for the universities.

Meanwhile, the revamped Ministry of Science and Technology has appointed its former vice-minister, Huang Qitao, previously director of the State Bureau for Nuclear Safety under the State Science and Technology Commission, to head its investment arm, China Venturetech Investment Corporation.

Officials quoted in the South China Morning Post newspaper say that although the appointment of a former vice-minister did not necessarily mean an upgrade for China Venturetech, the move was likely to sharpen the company's teeth in the long run.

David Swinbanks 